\title{
The Subjugation of Canadian Wildlife: Failures of Principle and Policy
}

\author{
Max Foran. 2018. McGill-Queen's University Press. 439 pages, 39.95 CAD, Cloth.
}

THIS IS A VERY IMPORTANT BOOK. The title of the book very aptly sums up its contents. It is not a balanced account of wildlife management in Canada but a polemic about its failures. As such, it is an uncomfortable read for (full-disclosure) an ex-employee of Environment Canada. I began by being very resistant to the central message of the book: that our failure to protect Canadian wildlife stems from a "homocentric" approach to nature, but by the end I was, if not converted, at least much more respectful of the author's arguments. Moreover, his contentions are extensively documented in 120 pages of small-type notes and bibliography, so these are well-founded arguments.

The book is in two sections: Part 1 deals with our "belief system" relating to nature and how it manifests itself in the treatment of predators, especially apex predators (wolves, grizzlies, and Cougars [Puma concolor]), as well as 'other wildlife' exemplified by the contentious spring hunt for Black Bears (Ursus americanus), Ontario's Mourning Dove (Zenaida macroura) hunt, and the notorious Newfoundland seal hunt. Part 2 deals with wildlife habitats and how we manage them, including a very useful discussion of the various legislative tools available to the Government of Canada, the provinces, and the territories and how they are being applied (or misapplied). This section deals at length with the Species at Risk Act (SARA), where Environment Canada is the villain of the piece, as well as with the establishment and management of protected areas, in which Parks Canada is featured as a major sinner. Among the good guys exposing the sins of the bureaucracy, Ecojustice and the Canadian Parks and Wilderness Society feature prominently.

Two themes run through the book: the first is the idea that animals, at least higher vertebrates, have a capacity for suffering that should require more humane treatment by us than is currently the norm. This theme echoes, in a more formal and scholarly manner, the concerns of Wohlleben's book covered in the previous review (Canadian Field Naturalist 132: 76, https://doi.org/ 10.22621/cfn.v132vili.2127). In fact, the two books make an interesting contrast in styles, with Wohlleben trying to convince us gently and humorously to be nicer to animals, while Foran hits us on the head with a twoby-four.

The second theme is the over-riding influence of economics, in the form of human security, jobs, and profit, in determining the outcomes of human-wildlife conflicts. This is hardly news, but the very detailed descrip- tions of events surrounding the cases of the Black-tailed Prairie Dog (Cynomys ludovicianus), the Greater Sagegrouse (Centrocercus urophasianus), the Nooksack Dace (Rhinichthys cataractae - Chehalis lineage), the Southern Resident Killer Whales (Orcinus orca), and others, highlight the sort of wilful blindness that goes into attempts to satisfy both economic and environmental interests. These sections would be very valuable reading for any politicians or public servants engaged in implementing SARA. They illustrate the fact that, in a society where information is readily available, decisions are open to the judgement of history.

I did have some caveats about the book. In a work that deals, among other things, with the ethics of hunting, the word 'meat' never appears. Nor was our relationship with pets or domestic animals discussed. But the belief system that the author laments, in which animals are treated as disposable resources, surely stems from our carnivorous habits. The heavy hunting of Moose (Alces americanus) in Newfoundland, for instance, treated as inhumane culling in the book, provides a very important element in the local diet. The same goes for deer hunting in Haida Gwaii and doubtless in many other places, even ignoring the obvious needs of indigenous peoples, especially the Inuit. Culling - the killing of animals to adjust ecosystem imbalances - comes in for much criticism, but the many cases where unique local ecosystems are being very clearly degraded by introduced species (e.g., rats or Raccoons [Procyon lotor] on seabird colonies, deer on Anticosti Island) are not considered. In fact, the author casts doubt on the validity of any sort of cull carried out with a view to rebalancing the ecosystem, claiming we do not have sufficient knowledge of ecosystem dynamics.

For me, among the most distressing shortcomings of our attempts to conserve wildlife in Canada is the fact that, despite the vast size of the country, many of our protected areas are too small to support viable populations of large mammals. You have to ask yourself whether, if a large country like Canada, with a welleducated population, generally inclined to look favourably on wildlife, cannot manage its wild species sustainably, what hope is there for the planet as a whole? The wake-up calls have been so loud, for so long, that our brains no longer hear them. Perhaps that is why Max Foran felt he had to adopt such a strident tone in this book. It is a very sobering read.

TONY GASTON Ottawa, ON, Canada 